\title{
'HALF INDIANS', ADOPTED 'GERMANS' AND 'AFGHAN INDIANS' \\ On claims of 'Indianness' and their contestations in Germany
}

\section{Transforming Cultures eJ ournal, \\ Vol. 3 No 1, February 2008 http:// epress.lib.uts.edu.au/journals/TfC}

\section{Urmila Goel $^{1}$}

The German internet portal <http://www.theinder.net>, called the Indernet, calls itself the "Indian Online Community". ${ }^{2}$ In its name, logo and project description ${ }^{3}$ there is an explicit reference made to 'India'. Up to recently the reference was even more clearly to 'Indians' and more particularly to 'Indians of the second generation'. ${ }^{4}$ In my research project "The virtual second generation" on the Indernet I pursue the question why the editors and users of the internet portal, who almost all are settled and socialised in 'Germany', have thus created an 'Indian' space. Why do they define themselves as 'Indian' and what does this mean to them?

In the course of my interviews with editors, users and observers of the Indernet I have spoken to many, whose claim to 'Indianness' is shared by their environment and where it is thus accepted without questions. But there were also several among my interview partners, who claim or would like to claim 'Indianness' for themselves, but cannot do so

\footnotetext{
${ }^{1}$ Urmila Goel, is post-doctoral researcher in social and cultural anthropology at the European University Viadrina in Frankfurt/Oder, Germany.

${ }^{2}<$ http://www.theinder.net $>(04.11 .06)$.

${ }^{3}<\mathrm{http}$ //www.indien-netzwerk.de/logo/projekt/projekt-deu.htm> (05.11.06).

4 The focus on 'Indians' and especially 'Indians of the second generation' was explicit until the project description was reformulated in the summer of 2006 (compare

$<$ http://www.theinder.net/logo/projekt/projekt-deu.htm> 28.02.2006). Now the focus has shifted from 'Indians' to 'India'.

${ }^{5}$ The research project has been funded by the Volkswagen Foundation. A three month fellowship granted by the Asia Centre of the University of New England in Armidale, Australia gave me the opportunity to present and complete my research in Australia. More on the research project can be found on $<$ http://www.urmila.de>.
} 
unquestioned. There are doubts among others as to the eligibility of their claim. They are seen to be deviating too much from the fictitious prototype ${ }^{6}$ of an 'Indian in Germany' to unquestionably be accepted as such. In this article I will discuss the claims to and contestations of 'Indianness' of these people on the margin of 'Indianness' in order to analyse the constructions of 'Indianness' among 'Indians of the second generation' in 'Germany'. The focus is put on those whose 'Indianness' is not unquestionable in order to illustrate how 'national', 'ethnic' and 'cultural' identities are imagined in the context of othering and racism. Ien Ang in her discussions of 'Chineseness" similarly focuses on the margins to analyse it's fixations and contestations. Like Ang I understand 'Indianness' as something context-specific and socially constructed. To adapt a quote by her: ${ }^{8}$

“... Chineseness [or Indianness or Germanness or ...] is a category whose meanings are not fixed and pregiven, but constantly renegotiated and rearticulated, both inside and outside China [or India or Germany or .... ."

Theoretically this article is thus based on the argument that social identities and groups are not 'naturally' given but rather the result of social constructions. ${ }^{9}$ These discursive constructions are part of the hierarchical structuring of societies, in particular through racism $^{10}$, and are thus context specific differing from region to region and in time. The perception of the social identities and the reactions to them depend on the social position of the individual within the hierarchy. Those within the hegemonic position reproduce ascriptions, which secure their privileges. Those marginalised by the

\footnotetext{
${ }^{6}$ The concept of the fictitious prototype I am adapting from Paul Mecheril (2003, 211-212), Prekäre Verhältnisse. Über natio-ethno-kulturelle (Mehrfach-)Zugehörigkeiten, Münster. The prototype is fictitious as it is solely an imagination and it is a prototype because the collective imagination determines, who is considered to belong to a particular 'national' context and who not. I will return to this concept in more detail later in the article.

${ }^{7}$ Ien Ang (2001) On not speaking Chinese - Living between Asia and the West, London and New York: Routledge.

${ }^{8}$ See Ang (2001: 25).

${ }^{9}$ On the constructions of social identities see: Richard Jenkins (1997) Rethinking ethnicity - arguments and explorations, London; Anthony Cohen (1985) The symbolic construction of community, London; Fredrik Barth (1969) Ethnic Groups and Boundaries, Boston, and Rogers Brubaker (2004) Ethnicity without groups, Cambridge: Harvard University Press.

${ }^{10}$ On racism see: Stuart Hall (2000) "Rassismus als ideologischer Diskurs“, in Nora Räthzel (ed.) (2000) Theorien über Rassismus, Hamburg: Argument, 7-16; Robert Miles (2000) "Bedeutungskonstitution und der Begriff des Rassismus“, in Nora Räthzel (ed.) (2000) Theorien über Rassismus, Hamburg: Argument, 17-33, and Paul Mecheril (2003).
} 
hierarchical order have to develop strategies and self-definitions in reaction to the powerful discourses. The social identities are thus never finally fixed, they are continuously adapted and are interdependent. ${ }^{11}$ They need to be analysed in their complex construction processes and in their respective contexts, which for this article is contemporary 'Germany'.

In this article I mark these constructed and ambiguous categories in inverted commas. Not only 'Indianness', which is to be analysed in this article, is ambiguous, but also the terms 'India' and 'Germany'. To what do they refer? To the current political state in its geographical boundaries? To a succession of political entities in a certain area? To some notion of 'culture'? When talking of 'Germany' my interview partners and I in most cases implicitly seem to refer to 'Western Germany' today and the Federal Republic of Germany before unification. In most interactions we 'West Germans' are not aware of the ambiguity of the term 'Germany'. 'Eastern Germany' and the German Democratic Republic are mostly ignored. Similarly 'India' is a term, which is used in reference to many different meanings. As Rushdie ${ }^{12}$ argues for the category of 'Indian' writers:
"England's Indian writers are by no means all the same type of animal. Some of us, for instance, are Pakistani. Others Bangladeshi. Others West, or East, or even South African. And V.S. Naipaul, by now, is something else entirely. This word 'Indian' is getting to be a pretty scattered concept. Indian writers in England include political exiles, first-generation migrants, affluent expatriates, whose residence here is frequently temporary, naturalized Britons, and people born here who may never have laid eyes on the subcontinent."

I have already used the expression 'Indians of the second generation'. It is a term widely used both in research and public discourses. There is some debate about what it actually means, but the general connotation is that the 'second generation' are the children of 'Indian' migrants. ${ }^{13}$ In my research I also started with this understanding of the term,

\footnotetext{
${ }^{11}$ Compare Jenkins' (1997) concept of transactional ethnicity.

${ }^{12}$ Salman Rushdie (1991) "Imaginary Homelands", in Salman Rushdie, Imaginary Homelands, London: Granta Books, 16.

${ }^{13}$ In the 'Indian' context those, who have migrated from 'India' to other parts of the world, are called 'Non-Resident Indians' (NRI), thus emphasising their further (ascribed or desired) linkage to the 'mother country'. The 'second generation' is understood to be either part of this category or to be the direct descendants of the NRIs.
} 
but have now shifted the emphasis. I use the term 'Indians of the second generation' for those who were socialised in 'Germany' and are marked there as 'Indians'. This encompasses the children of migrants as well as others who are marked as 'Indians'. Among the latter there are people who were adopted as small children from 'South Asia' by 'white' ${ }^{, 14}$ parents as well as biological children of 'South Asians', who never had contact with these and further generations, if they are still marked by physiognomic or social attributes as 'Indians' in 'Germany'. This definition has developed both out of my theoretical deliberation and empirical observation. Rather than focussing on a supposed essence through 'origin' it highlights the impact of ascription and othering in the racist society 'Germany'. ${ }^{15}$ Empirically it encompasses all those, whom I have met in 'spaces of the second generation', ${ }^{16}$ who express a sense of belongingness there and who thus indicate some degree of identification with the term 'second generation'. Rather than as a self-description I, however, consider the term to be an analytical category to focus on individuals, who experience certain forms of ascription and othering in 'Germany'. 17

A concept closely related to this interpretation of 'second generation' and which informed it, is Paul Mecheril's concept of 'Andere Deutsche', which is best translated as 'Other Germans'. ${ }^{18}$ Mecheril defines 'Germans' independently of citizenship,

\footnotetext{
${ }^{14}$ Based on Critical Whiteness Studies (in Germany in particular Maureen Maisha Eggers, Grada Kilomba, Peggy Piesche and Susan Arndt (eds.) (2005) Mythen, Masken, Subjekte - Kritische Weißseinsforschung in Deutschland, Münster: Unrast.) I define 'white' as the hegemonial and unmarked social position in a society structured on racist principles.

${ }^{15}$ The main theoretical foundations of this article are the works of Paul Mecheril on 'Other Germans' and multiple natio-ethno-cultural belongingness, see in particular Mecheril (2003). Other theoretical approaches which have guided me in this approach are among others from 'Germany': Mark Terkessidis (2004) Die Banalität des Rassismus - Migranten zweiter Generation entwickeln eine neue Perspektive, Bielefeld./ Tarek Badawia (2002) "Der Dritte Stuhl": Eine Grounded Theory-Studie zum kreativen Umgang bildungserfolgreicher Immigrantenjugendlicher mit kultureller Differenz, Frankfurt/Main. and Christine Riegel (2004) Im Kampf um Zugehörigkeit und Anerkennung - Orientierungen und Handlungsformen von jungen Migrantinnen, Frankfurt. Similar thoughts can be found in Avtar Brah (1996) Cartographies of Diaspora - Contesting identities, London, and Gerd Baumann (1996) Contesting Culture - Discourses of identity in multi-ethnic London, Cambridge.

${ }^{16}$ For a discussion of 'spaces of the second generation' see Kathleen Heft and Urmila Goel (2006) Räume der zweiten Generation - Dokumentation eines Workshops, Frankfurt/Oder: Viadrina.

${ }^{17}$ Compare Paul Mecheril (2004) "Andere Deutsche gibt es nicht. Zusammenhänge zwischen subalterner Erfahrung und diskursiver Praxis", in AntiDiskriminierungsBüro Köln und cyberNomads (ed.) The Black Book. Deutschlands Häutungen, Frankfurt, 82-90.

${ }^{18}$ The concept 'Other Germans' was first developed in Paul Mecheril and Thomas Teo (1994) (ed.) Andere Deutsche. Zur Lebenssituation von Menschen multiethnischer und multikultureller Herkunft, Berlin, and then further developed in Paul Mecheril (1997) "Rassismuserfahrungen von Anderen Deutschen - eine Einzelfallbetrachtung", in Paul Mecheril and Thomas Teo (eds.) Psychologie und Rassismus, Hamburg, 175-201, as well as Mecheril (2003).
} 
ancestry or practiced culture as those, who have lived, live and will live in 'Germany'. As in the logic of the 'German' nation state and implemented in its structures their belongingness to 'Germany' is, however, on the basis of physiognomic or social markers contested, ${ }^{19}$ they are not unquestioned but rather othered 'Germans'. Mecheril argues they are doubly othered as they experience themselves to be seen differently both from the 'white German' society and from their ascribed 'original' society. ${ }^{20}$ 'Indians of the second generation' in my definition are a subgroup of this analytical category of 'Other Germans'.

The focus of this article is to analyse claims and contestations of 'Indianness' in 'Germany'. It deals with people, who live in 'Germany', whom Mecheril classifies as 'Germans' and who in 'Germany' define themselves as 'Indians'. In all of this 'India' plays a role most of all as an imagination. Due to a lack of contact and own experiences with the real 'India', if that exists at all, 'India' and the discourses there, play only a marginal role for those portrayed here. The analysis, accordingly, does not refer to the latter but rather to German discourses, racist structures and terms, thus drawing a 'German' perspective on a transnational topic. It would be a different research project to look from an 'Indian' perspective on the same people. The topic of research, the questions raised, the terms used and the interlinkages studied would be different, because the researcher would be positioned differently, not only geographically but also relationally and theoretically. Similarly, a 'German' analysis necessarily has to be different from one conducted in the 'British' context. While in the latter hyphenated identities and what Hall ${ }^{21}$ calls 'new ethnicities' are already part of popular discourses and self-definitions, in 'Germany' the idea of 'pure' identities still dominates the discourses and self-positionings. ${ }^{22}$ Concepts and terms accordingly not only need to be adapted to the specific contexts, they are also not equally adaptable.

\footnotetext{
${ }^{19}$ Mecheril (2003) discusses this in detail.

${ }^{20}$ Compare Ang (2001: 26-28) on how peranakan 'Chinese' are defined as the others in 'Indonesia', are categorised as 'Chinese' and consider themselves as such, but then experience othering also in 'China'.

${ }^{21}$ Stuart Hall (1992) “New Ethnicities”, in James Donald and Ali Rattansi (eds.) 'Race', culture \& difference, London: Sage, 252-259.

${ }^{22}$ Mecheril (2003) discusses the concept of univocal natio-ethno-cultural belongingness in 'Germany' in detail.
} 
In the course of the research project I conducted more than seventy narrative interviews with editors, users and observers of the Indernet, who live in 'Germany', 'Switzerland' and 'Austria'. ${ }^{23}$ Most belong to the category of 'Indians of the second generation', some were migrants from 'South Asia' and others 'white Germans'. The interviews centred on the experiences with and observations of the Indernet and extended into related fields.

The Indernet is an internet portal, which was established in the summer of 2000 by three young male 'Indians of the second generation'. It was motivated by their fascination with the technology internet, their search for others like themselves (in 'national' categories) and the racist campaign "Kinder statt Inder". ${ }^{24}$ Following its establishment in the year 2000 the Indernet in the first time grew quickly in content, users and editors. Since a few years ago it has more or less stabilised on a high level still attracting new users. It provides editorial information about 'India' and 'India in Germany' and interactive elements for communication. It has established itself as one of the most important 'spaces of the second generation' in 'Germany' and is well known beyond the users. ${ }^{25}$ One of the most important services the Indernet offers is a calendar of 'Indian' parties. The latter provide offline 'spaces of the second generation' where 'Indians of the second generation' can meet and represent themselves. ${ }^{26}$

The Indernet was the space which guided my field research, all my interview partners were somehow related to it. The topics of the interviews, however, went far beyond issues concerning this particular space. This article deals with some of these issues rather than directly with the Indernet. ${ }^{27}$ Some of the quoted interview partners are

\footnotetext{
${ }^{23}$ Two of my interview partners were studying in 'Great Britain' at the time of the interview.

${ }^{24}$ The slogan "Kinder statt Inder", which translates to "children instead of Indians', was used by the conservative opposition to counter the 'GreenCard' scheme of the 'German' government to attract foreign IT professionals, in particular those from 'India'. The opposition argued that rather than encouraging immigration the government should educate 'German' children to become IT professionals. It was the first openly racist campaign in 'Germany' against 'Indians'.

${ }^{25}$ See Urmila Goel (2005) "Fatima and theinder.net - A refuge in virtual space", in Angelika Fitz, Merle Kröger, Alexandra Schneider und Dorothee Wenner (ed.) Import Export - Cultural Transfer - India, Germany, Austria, Berlin: Parhas Verlag 201-207, for an analysis of the Indernet.

${ }^{26}$ The internet space of the 'Overseas Chinese' described in Ang (2001: 57-70) differs considerably from the Indernet as the former is set up as a global network and has a clear political aim.

${ }^{27}$ For an analysis of the Indernet see, for example, Goel (2005) as well as Urmila Goel (2008) “The German internet portal Indernet - A space for multiple belongingness", in Gerard Goggin and Mark McClelland (eds.) Internationalizing Internet Studies, New York: Routledge (forthcoming).
} 
regular users of the virtual space, others not at all. In this article they are not primarily linked by the virtual space but rather by all of them claiming some form of 'Indianness'. To analyse these individual claims against the backdrop of 'Germany' is this article's aim.

In it I will thus discuss claims of 'Indianness' and their contestations as they were illustrated to me in the interviews. I will start with describing the claims of some of those most commonly referred to as 'Half Indians', since they have only one 'Indian' parent. Then I will continue to discuss the claims of those, who were adopted by 'white' parents, and finally I will introduce the claims of 'Afghan Indians'. Following the description and discussion of the material I will analyse it from a theoretical perspective, using in particular Paul Mecheril's work.

\section{'Half Indians'}

'Half Indians' is a term I heard very often as a self-description and a categorisation in my interviews and regularly read in publications off- and online. ${ }^{28} \mathrm{I}$ am also confronted with it as an external categorisation of myself in everyday conversations. It is a term most commonly used for those who have one parent, who is marked as an 'Indian' and one who is a 'white German'. Another expression for this category I have come across frequently is 'Half half', while 'Half German' seems to be hardly used in 'Germany'. The German term 'Mischling', which is similar to 'half-caste', is not that common any more but occasionally appears both as a categorisation and as a self-description. Even more so than the other terms it refers to racist ideology as it is a term used in biology to describe a crossbreed and has been appropriated among other racist ideologies by the national socialists in their classification of 'Jews'. While the qualification half is on the first sight less ideologically loaded, it contains the idea that two distinct 'races' are genetically mixed and the product consists of these two. It also suggests that the mixture

\footnotetext{
${ }^{28}$ See for example Christiane Molt (2006) "In search of Indo-European identities", in Klaus Voll and Doreen Beierlein (ed.) Rising India - Europe's Partner?, Berlin: Weißensee Verlag, 963-969, as well as the self-description of the journalist Marc Saha: $<$ http://www.wdr5.de/funkhauseuropa/team/detail.phtml?teamid=31> (06.11.06), a discussion among soccer fans $<$ http://www.dsc4ever.de/thread.php?threadid $=121>(06.11 .06)$ or a discussion on the Indernet: $<$ http://www.bharatsutra.de/phpBB2/viewtopic.php?p=108642\&sid=de95e3ce8d5b3d6609ed6e6ccaf5716 c $>$ (06.11.06).
} 
is less than the original. It is not double but half. ${ }^{29}$ The terms 'binational' or 'bicultural' would carry the opposite meaning of the mixture being more than what was there before. But the usage of these terms seems to be restricted to academic and activist circles, and it continues to carry the essentialist notion of two distinct 'nations' or 'cultures' meeting in it. ${ }^{30}$

If thus my interview partners talk of 'Half Indians' they are qualifying the 'Indianness' of those thus categorised. One of my interview partners, lets call him Subhas, ${ }^{31}$ who is the son of two migrants from 'India', said this quite openly to me: "Most of the Half Indians are German." ${ }^{32}$ From the context it was clear that this was not a value-free observation, but carried also the meaning that they have not kept their 'Indianness' sufficiently, that they are not really 'Indian' and need to be distinguished from the 'real' ones. Even if Subhas' opinion is not representative for 'Indians of the second generation' in general, it is one which floats around, is articulated occasionally and feared sometimes by those thus categorisable. It is a categorisation which they are always in danger of facing. They thus need to be prepared to deal with the accusation of not keeping their 'Indianness' sufficiently and need to develop strategies to do so. These can be manifold. They can reach from the extreme of attempting to 'Indianise' as much as possible on the one side to that of denying any 'Indianness' on the other.

In my observation many people with only one parent marked as an 'Indian' attend 'spaces of the second generation' and consider themselves to be 'Indians of the second generation'. I myself always considered myself thus and was active in organising events for the 'second generation' independent of their 'purity' of descent. Among the users and editors of the Indernet there are several, who have a 'white' parent. Even Marcus, one of the early editors, has a 'white German' mother. Nonetheless, the belongingness

\footnotetext{
${ }^{29}$ Compare Mecheril's (2003, 276-294) analysis of Ayşe's self-description. He interpretes her use of the term 'half half' as an indication of her feeling doubly othered and not-belonging.

30 The colonial term 'Anglo Indian' similarly carries the notion of two distinct 'nations' or 'cultures' being mixed and already as such is problematic.

${ }^{31}$ All names are changed to ensure anonymity. I choose names marked as 'Indian' respectively 'German' as a pseudonym, where the actual name is marked similarly.

${ }^{32}$ The interviews were recorded and transcribed. For this I am indebted in particular to Navina and Alina Khatib, Thomas Steller and Mareile Paske. I conducted the interviews in German. The English translations are my own.
} 
of these 'impure ${ }^{33}$ to an 'Indian' space is not unquestioned and there is a permanent pressure for them to legitimise it. In the following I will give four examples of contested 'Indianness' of 'Half Indians'.

Christiane, one early user of the Indernet, was very enthusiastic about finding the Indernet. She was looking for information about the country, in which her mother had grown up and hardly ever told her anything about. Christiane had read books about 'India' and had gone to 'Indian' events in 'Germany'. She was always on the lookout for more information and thus when at the beginning of her undergraduate studies she had come across the Indernet, she became a very active user and interacted also with the editors, who at this stage were still easily visible and approachable for the users. She, however, did not feel quite comfortable with the 'Indianness' of the Indernet, rather than considering it an "Indian Online Community" she would have liked it to be a "German-Indian Online Community". Years later, when she had already left the Indernet as an active user and I interviewed her, she told me: "The editors were, at least at the beginning, very Indian ... I was virtually the half-caste." ${ }^{34}$ This she expressed, even though she was not the only one with a 'white German' parent. Marcus was there as well.

At the time of the interview I had not made this distinction yet, I had not yet interviewed Subhas and was surprised about the way in which Christiane felt othered. Her experiences, however, where echoed in other interviews. Samira, an early observer, who has an even more disputed claim to 'Indianness' as her father's family as Muslims migrated to the newly founded 'Pakistan' following the division of 'British India', also told me that she perceived the Indernet to be a space for "I assume mononationally cultured, not the binational, and also certainly those of Indian descent, with parents of Indian descent." Samira thus did not really feel it was a space for herself, in particular as she felt further alienated by what on the one hand she considered to be a Hindu orientation of the editors and on the other the male and heteronormative character of the space. $^{35}$

\footnotetext{
${ }^{33}$ They are considered 'impure' in the dominant logic of a univocal 'national' belongingness as has been argued by Mecheril (2003).

${ }^{34}$ Christiane uses the Geman term 'Mischling', which is used in racist discourses.

${ }^{35}$ For an analysis of the norms and boundaries of the Indernet see Urmila Goel (2007) "'Kinder statt Inder' - Normen, Grenzen und das Indernet", in Christine Riegel and Thomas Geisen (eds.) Jugend,
} 
If the rather new user Peter saw a Hindu orientation on the Indernet, this would not have been of any concern for him. In fact it would have confirmed his view of what 'India' is. Having grown up without any person identified as an 'Indian' in his environment all he knows about the place, where his biological father was born and raised, is what he knows through the media and his mother, who was deserted by the 'Indian' father. Hinduism plays a central part in Peter's image of 'India'. One of his first questions in the forum was whether as the son of a Hindu he was one as well. Peter, who is solely marked by his biological father but not by other physiognomic or social attributes as an 'Indian', wears a necklace with an Om-sign and uses a nickname stereotypically related to 'India' in 'Germany'. He tells me in the interview that he has always felt that something is missing and that 'India' is his additional 'home'. ${ }^{36}$ As a consequence he is actively looking for 'Indians' with whom to interact. Since he was not successful in this offline, he started to be an active user on the Indernet. He also used the opportunity to attend offline meetings of Indernet users. There, in contrast to the virtual space, physiognomic markers attain a major importance and he experienced that his belongingness was very much questioned. ${ }^{37}$ In fact he was asked: "Are you really an Indian?" Some users suspected that he was a 'white' guy, who was that much fascinated by 'India' that he claimed to be one of them.

Peter deviates even more than Christiane from what is generally considered to be an 'Indian'. He is even less physiognomically marked and even less socialised as an 'Indian', thus his own claim of 'Indianness' is questioned explicitly. In his search for his 'Indian' part, he has to deal with or ignore the denial of belongingness he is continuously faced with.

This stands in total contrast to the situation of the early editor Marcus. When Subhas made his remark about the 'Germanness' of 'Half Indians' to me he explicitly excluded

\footnotetext{
Zugehörigkeit und Migration, Wiesbaden: VS Verlag, 163-181. For the Hindu orientation of 'Indian' virtual spaces compare, for example, Ananda Mitra (1997) "Virtual commonality: Looking for India on the internet", in Steven Jones (ed.) Virtual Culture. Identity and communication in cybersociety, London: Sage, 55-79, and for an explicitly feminist 'South Asian' virtual space Radhika Gajjala (2004) cyber selves - Feminist ethnographies of South Asian women, Walnut Creek: Altamira Press.

${ }^{36}$ The German term 'Heimat', which he used, has a much stronger connotation than 'home'. It implies original belongingness and is a central part of 'German' nationalist discourses.

${ }^{37}$ On the Indernet the standard assumption about the other users is that they are 'Indians of the second generation'. As online the only markers available to verify or falsify this are the written selfrepresentations of the users this assumption is much less challenged than offline, where other social and physiognomic markers are observable and determine the way we see a person.
} 
Marcus from this. This contrasts with the latter explicitly defining himself as "HalfIndian" in the interview and arguing there as well as in forum discussions that "Indians of the second generation' (including himself) are predominantly 'German' as a consequence of their socialisation in 'Germany'. Marcus is nonetheless accepted by Subhas as an exception as he can speak Hindi ${ }^{38}$ and knows a lot about 'India', something which is hardly found even among those with two 'Indian' parents in 'Germany'. It thus seems that at least in the perspective of Subhas 'Indianness' is defined not only through ancestry but also through competence in cultural practices.

I doubt, however, that he would refuse anybody with two 'Indian' parents the claim to 'Indianness' even if that person spoke no 'Indian' language and knew nothing about 'Indian' cultural practices. Subhas would in my impression rather regret that this 'Indian' has lost the link to his or her 'culture'. 39 In fact in reference to 'Germany' he explicitly mentions to me the importance of ancestry: "I am an Indian. I would never call myself a German. In Germany ancestry plays a major role.”

\section{Adopted 'Germans'}

Ancestry would qualify those as 'South Asians', who were adopted from 'South Asia' by 'white' parents in 'Germany'. Those, who I have met and interviewed, are physiognomically much more marked as 'Indians' than are Christiane, Peter, Samira, Marcus or me. Thus if their personal history is not known to others they can and do at the first sight pass as 'Indians' easily. They experience that they are spoken to in an 'Indian' language by others marked as 'Indians' or considered 'Indians' by 'white' people. But most of them have been brought up solely in 'white' families, have hardly any memory of 'South Asia' and mostly do not know anybody socialised in 'South Asia' closely. The 26 year old Martin, who was adopted from 'India' at the age of three years, thus clearly defines himself as 'German':

${ }^{38}$ As there are a number of different languages being spoken in 'India' and English is one of these, the role of speaking Hindi in determining 'Indianness' is, however, less pronounced as that of speaking Chinese in determining 'Chineseness' as shown by Ang (2001).

${ }^{39}$ Compare Ang's (2001) experiences as being considered 'Chinese' on the basis of physical markers. Her not speaking Chinese is rather considered as a neglect on her part than an indication of her not being 'Chinese' in essence. 
"I have always considered myself a German, because I never have known anything else. I notice naturally, that I do meet boundaries. When one sits at the cashpoint, the first one says 'Where do you come from?', the next 'You are no German, are you?' or 'You do not come from here?' or they say 'You speak German very well.' Then one notices the boundaries. But otherwise, I was brought up like this, I never knew anything else, I do not know the culture, I do not speak the language, I have no connection to India, I have no relatives there."

But in this clear positioning in precarious 'Germanness' and in distancing himself from 'Indianness' Martin is the exception among the adopted 'Germans' I interviewed. For most others the unknown place of 'origin' 'India' becomes an important place of reference. They refer to it as an 'imaginary homeland' as Rushdie ${ }^{40}$ calls it. But like Peter's their imaginations are even less linked to the 'real India' than those of the 'Indians of the second generation', who have grown up with at least one parent marked as an 'Indian'. Their imagination is hardly built on any real experiences with 'India' and much more on the myths prevalent in 'Germany'. In the following I will discuss three claims to 'Indianness' by adopted 'Germans.

Seba lives in a small 'West German' town, where according to him he is almost the only "coloured person". We had agreed to meet at the small railway station of his home town for the interview. But when I reach there, I cannot find him. It takes some time and calls on the mobile phone until we actually meet. He had seen me but did not recognise me as the interviewer. He had expected an 'Indian' and I do not look 'Indian' to him. This lack of recognition I know from appointments with 'white Germans' and to some extent also with 'South Asians' in 'South Asia'. However in my experience most of the 'Indians of the second generation', who have grown up with a parent marked as an 'Indian', do recognise me as one of them. The physiognomic attributes indicating 'Indianness' seem to be different for those who come from an environment where 'pureness' dominates, and those who are used to hybrid ${ }^{41}$ contexts. 'Pureness' in Seba's context, however,

\footnotetext{
${ }^{40}$ See Rushdie (1991: 10).

${ }^{41}$ The concept of hybridity has been developed by Homi K. Bhabha (1994) The location of culture, London. It is used by Mecheril (2003), when he develops his analysis of multiple natio-ethno-cultural belongingness to which I will come back later in the article, and also by Ang (2001) in discussing the situation of 'Overseas Chinese'.
} 
does not refer to 'pureness' of 'national origin'. Seba did not grow up in a (to use Samira's term) mononational family. His social mother is a migrant from close by Switzerland. He thus does know the belongingness to several 'national' contexts at the same time. But Seba has grown up in an environment which was almost purely 'white'. He thus takes his own physiognomic markers as an indicator of 'Indianness', as it is the only one he knows, and accordingly does not recognise me.

Seba does not know anybody else who is marked as an 'Indian'. Thus he surfed the internet to find others like himself and came across the Indernet. His first post in the forum was (similar to the nature of Peter's first post) an inquiry about the meaning of his second 'Indian' name. He was looking for an expertise he was lacking, assuming as most 'white Germans' do that 'Indian' names have a special meaning. He considered his name 'Indian' although he was born by a 'Tamil' mother in 'Sri Lanka'. To my question, why he uses an 'Indian' portal and not a 'Tamil' one, he replied: "For me it is all the same." 42 He talks of meeting others, "who have more or less the same interest and origin as I have". The differentiations somebody like Subhas makes are unknown to him. From his perspective of being almost the only 'coloured' person in a small 'West German' town all of 'South Asia' is one. His ignorance of 'India' and 'Indian' differentiations might be one of the reasons why he does not seem to really become a part of those Indernet users, who both on the internet portal and through more individual modes of communication are in intensive contact with each other. Another reason might be that his interests are not really similar to those of the other users.

While Seba's attempts to gain information about his ascribed place of 'origin' are restricted to surfing the internet, Ashvin is pursuing the task much more actively. He was adopted at the age of a few months from 'India' and lives now in a small 'West German' town. In contrast to Seba's family, however, Ashvin's had always had contact with 'India'. His 'white' social mother travelled there regularly and took Ashvin, when he was 15 years old, to his birthplace. At that time he did not like 'India' at all. He remembers it as dirty and alien. At this stage of his development he still considered himself (as Martin still does) a 'German'. Only later when he started experiencing racism consciously, he understood that he is not accepted as a 'German' and is rather

\footnotetext{
${ }^{42}$ In 'India' and 'Sri Lanka' the differentiation between the two countries would be very relevant. It could be broken by a joint reference to a 'Tamil' identity. But Seba is ignorant of both the dividing and the potentially relating points of reference.
} 
considered a 'foreigner'. ${ }^{43}$ As a consequence (and much more so than Martin) he began to become more interested in 'India' and finally chose to study indology. He started attending 'Indian' spaces such as seminars, parties and internet portals in order to meet others like himself. But the parties organised at the place where he studied did not offer him what he was looking for. On the one hand he explains: "with the time the number of Indians coming was decreasing and there were more and more Europeans coming". On the other hand he did not like the 'Indians' he met there. On the Indernet he was no more successful, as he considered it to offer too little interaction. So he finally ended on the international matrimonial internet portal <http:/www.shadi.com>. "Shadi" is the Hindi term for wedding. The portal is a community of users, who all identify as 'Indians' and live dispersed all over the world (including 'India'). Shadi provides detailed profiles of them and the possibility to interact with each other. When I interviewed Ashvin he just had found his second girl-friend through Shadi. The first one had been based in London, the second one is an 'Indian of the second generation' in 'Germany' with two parents, who migrated from 'India'. To my question, why he was in particular looking for an 'Indian' partner Ashvin replied:

"Because I am myself convinced that an Indian partner or one with Indian roots suits me better, because I .... If she is like I am a bit in between the two cultures. ... Maybe an Indian from India would not suit me in the long run, but neither would a German woman, who is linked only to Germany. It has to be somebody, who knows like myself both cultures and also maybe speaks both languages, has friends in both cultures, has travelled in both cultures .."

Ashvin is clearly looking for someone who has experienced similar things as himself in 'Germany'. It is interesting which terminology he uses to describe these experiences. He talks of two cultures in between which he is standing, when in fact he has been solely socialised in a 'white German' environment and has started getting acquainted with what might be called an 'Indian culture' only in the last few years and this predominantly in an academic setting. Either he considers culture as something which is inherited from the biological parents or he uses the term for something else he is experiencing. Furthermore, he is looking for somebody else who speaks both languages.

\footnotetext{
43 'Ausländer', which translates to 'foreigner' in English, is the term used most commonly in German to categorise those, who live in 'Germany' and are not considered to be 'Germans'.
} 
What languages are these? One most certainly is German. This is the language both he and his girl-friend speak as their main language. The other is implied to be an 'Indian' language. Ashvin has not learned one, when he was a child, but he is now studying Hindi at university. His girl-friend has been brought up with Malayalam. I do not know her, but judging from the many other 'Malayalis of the second generation' I know, she probably knows some basic Malayalam to talk about everyday issues and if she has gone to a Malayalam school she can also read and write a bit. But even if she is fluent in her mother tongue, it definitely is not the same language as the one Ashvin is studying. Malaylam and Hindi have no similarity, neither in script nor vocabulary nor sound. In 'India' such a difference of language often is the basis for 'ethnic' differentiation and exclusion. When I ask him about this contradiction to what he said, he replies: "it does not explicitly have to be the same ... She knows an Indian language and I am studying an Indian language. This is already in itself something linking us.”

It seems that rather than a practical congruence of cultural competence Ashvin is looking for a matching symbolic belongingness to 'India' and shared experiences of othering in 'Germany'. As in contrast to his girl-friend he was not raised in an 'Indian' environment the thing most common to both of them would be that they are both marked as 'Indians' in 'Germany' and that they thus both are ascribed with the same images of 'Indian culture' and essential 'Indianness'. In fact, Ashvin does add to his explanation for looking for an 'Indian' partner an experience with his 'white' environment: "Also my parents and my friends say that an Indian woman simply suits me better, harmonises better with me."

This sentiment is shared by Paul, who was born in 'Germany' of parents who are marked as 'Indians' and has lived since his first year with 'white' foster parents. When I ask him about the tendency among 'Indians of the second generation' to look for 'Indian' partners, he replies: "I can understand that one is looking for someone who is culturally similar to oneself and who also from the looks ... who is particularly attractive to oneself, because he is similar to oneself." Referring to his girlfriend, who is marked as a 'Turk' in 'Germany', he adds: "it is not a coincidence that I am together with a foreigner". While Paul, like Ashvin, refers to a common culture of sorts, he focuses more on the physiognomic markers in the search for commonality. Also in the rest of the interview he repeatedly refers to his body that differs from the others in his 
'white' family and his relatedness to 'foreigners' in general: "One has a similar humour. At first go there is a better understanding compared to when one meets Germans." $\mathrm{He}$ adds: "If one has lived as a foreigner for a long time in Germany, one has similar experiences." This reference to similar experiences and the recurring use of the term 'foreigner' suggests that Paul focuses more on the othering experienced in 'Germany' than on his supposed country of 'origin'.

Confused by his telling me that he was brought up as "a normal German" and his continued reference to the commonness with 'foreigners' I ask him whether he does consider himself a 'foreigner' and he replies: "I consider myself a German, but I am treated often as a foreigner, i.e. I am considered a foreigner." He furthermore also seems to consider himself an 'Indian', for example he explains his attendance at 'spaces of the second generation' with: "I just wanted to meet a few other Indians". Here again he adds: "It is actually a great experience to meet other people, who somehow are similar to one bodily, who look similar and who have a similar life background." Paul's focus (in contrast to Martin's) is clearly on physiognomic markers as these are the dominant one, which distinguish him from his 'white' environment.

From my own perception of the adopted 'Germans' I have to admit that while I experienced Martin, Seba and Ashvin despite their physiognomic markers and in accordance with my own set of markers as predominantly 'German', Paul passed for me as a 'Malayali of the second generation'. I always thought of him in this terms and had to actively remind myself that he was brought up by 'white' foster parents. The reason for this biased and essentialising perception on my side was probably that he does have biological parents, who fall within my category of 'Indian' migrants and I thus categorise him accordingly.

\section{'Afghan Indians'}

While I readily accepted Paul as an 'Indian of the second generation' it took me some time to understand why people, who I have learned to categorise as 'Afghans' since they were born in that country, consider themselves as 'Indians'. Early on in my research I heard that 'Afghans' were organising 'Indian' parties and that the webmaster of the Bollywood internet portal <http://www.happyindia.de> is an 'Afghan'. 
'Afghanistan' was very much present in the 'German' public since the 'US American' invasion there and I had had much contact with 'Afghans of the second generation', who were defining themselves explicitly as 'Afghans', were thinking about returning to 'Afghanistan' and were much involved in rebuilding the country. Thus I was surprised by hearing of 'Afghans' who consider themselves 'Indians'. What I had not thought of was that among the 'Afghans' living in 'Germany' there was a sizable number of Hindus and Sikhs, who do not identify with 'Muslim Afghanistan'. ${ }^{44}$ This I only began to understand when I started to interview the webmaster of happyindia and some of the party organisers. In the following I will introduce two of them.

Hari was born into a Sikh family in Kabul in the late 1970s. When his father in the early 1980s was in danger of being drafted, the family decided to flee to Europe. As Sikhs in 'Afghanistan' they were not feeling secure anyway. Hari tells me of threats they were exposed to as a minority. Their route to Europe first took them to Delhi, where they lived for a few years experiencing and surviving unharmed the violent riots against Sikhs in 1984. In the middle of the 1980s they finally came to 'Germany', were granted asylum, settled down in a 'West German' town with an 'Afghan Hindu' infrastructure and acquired the 'German' citizenship. Hari has ever since lived in 'Germany', has never visited 'Afghanistan', but has gone to 'India' several times.

Hari, like Subhas, does not consider himself a 'German': "I was brought up in many ways as a German. But I do not think that I will ever say I am a German. It is a culture, which is totally different, to which I can not belong $100 \%$." In the same way he does not think of himself as an 'Afghan'. When other 'Afghan' Hindus or Sikhs call themselves 'Afghans' he asks them: "You do not speak the language, you are no Muslims, you have a different culture, an Indian culture. How can you define yourself as Afghans?". Hari is very clear in his self-description, he is an 'Indian' and uses this term often in the interview. He argues his 'Indianness' as follows: "Home" ${ }^{45}$ is that country, where I belong culturally, religiously, concerning the language. Where I do not experience myself as something alien. And this definitely is India." For Hari 'national' belongingness is not so much determined through where your family has lived but

\footnotetext{
${ }^{44}$ Compare Ang's (2001) description of the 'minorities' in 'Indonesia'.

${ }^{45}$ Hari uses the German term 'Heimat', which as has been said before has a much stronger nationalist connotation than the English 'home'.
} 
predominantly through cultural practices and familiarity with them. But as he also knows that his claim to 'Indianness' is a precarious one, he argues the special situation of 'Afghan Indians': "We do not have a real home. Ok, we are originally Indians. ... But Indians are a bit different from us. We also aren't real Afghans. We thus are homeless ${ }^{46}$ and thus one has to define oneself somehow. And it is my opinion that I am more Indian than anything else." Here Hari clearly illustrates that (especially in a precarious situation) 'national' belongingness is something imagined and constructed. He has to make a decision to which 'national' context he belongs. He knows that no matter how he decides, his decision will be questioned and knowing this he stresses his 'Indianness' as he feels most comfortable with it.

But this decision of Hari and his usage of the term 'Indian' in the advertisement for his parties meets a lot of resistance among those unquestionably considered 'Indians of the second generation'. I was told in many interviews that there is a dislike of 'Afghan' party organisers and their claims to 'Indianness'. One musician told me that others asked him not to perform at such parties, because they are 'Afghans'. Rajesh, an 'Indian' party organiser, explains to me his dislike for some 'Afghan' parties' claim to 'Indianness', with them not playing 'Indian' but rather 'Turkish' and 'Arabic' music. Later on he says that it is not sufficient to play 'Indian' music to be part of the 'Indian community'. Finally Rajesh articulates his rejection of their claim very openly: "Then there is also the paradox: this is being organised by Afghans und I ask myself over and over again, where do they get the right from to represent Indian culture." He certainly does not grant it to them.

Harsha, another party organiser who was born in Kabul and came as a child to 'Germany', is annoyed by this exclusive claim. In the interview with me he repeatedly questions what 'Indianness' means and in particular attacks the notion of 'authenticity': "If we make mashed potatoes and we add a few of our spices, then it is Indian." This is also the approach he takes in organising his 'Indian' parties. He traces 'Indian' influences into 'Arabic' and 'Turkish' music and plays them as well. Rather than catering for the 'Indian' community, which he claims is less interested in 'Indian' music and more interested in partying together, he focuses on offering 'Indian' music. Like

\footnotetext{
${ }^{46}$ Again the German term 'heimatlos', which Hari uses, has a very different connotation from ,homeless' in English. It implies that you have no place where you belong, which in the normative discourses carries a negative connotation.
} 
Hari, Harsha considers his family, who have lived as Hindus for several generations in 'Afghanistan' to be 'Indian'. He argues that they originally migrated from Sindh to 'Afghanistan' and thus are "immigrated Indians" or "Afghan Indians". He says that he feels neither 'Indian' nor 'Afghan' and at the same time he feels both 'Indian' and 'Afghan'.

In his impression 'Indians of the second generation' in 'Germany' have little practical idea of what 'Indianness' is. Thus they imagine it on the basis of myths they are told and in reaction to experiences of othering: "What is supposed to be Indian? At home there is nothing Indian. They shop at Aldi, ${ }^{47}$ watch 'Who wants to be a millionaire?'. ${ }^{48}$ The only thing which is Indian are the Bollywood movies and maybe the clothes, partly the food and music. Not even the lifestyle is Indian. But then a German tells you: 'You are no German, because you do not look German.' Whatever that is supposed to mean. And then the people say to themselves: 'Then I must be an Indian. Ok, but India is cool.",

Harsha thus links the identification as an 'Indian' to the experiences of exclusion through the 'white German' society. It is not essence which defines 'Indianness', but it is rather a point of refuge, a positive identification, which is needed. In Harsha's impression the exclusion of the 'Afghans' from 'Indianness' results from this: “Then there is the Indian full of myths and testosterone and he starts to rail against me, because I am an Afghan."

\section{Markers of 'Indianness' in 'Germany'}

The discussion so far has shown that there are several markers, which are used alone or in combination to claim or contest 'Indianness'. Among these are first and foremost markers which refer to the body such as the genes, i.e. having biological parents or other ancestors from 'India', as well as physiognomic markers. ${ }^{49}$ Already the term 'Indians of the second generation' carries the connotation that 'Indianness' is hereditary, being

\footnotetext{
${ }^{47}$ Aldi is a 'German' supermarket chain.

${ }^{48}$ The 'German' version of this television format was very popular in 'Germany'.

${ }^{49}$ Compare Ang's (2001) experiences of being considered a 'Chinese' person on the basis of physiognomic markers.
} 
passed on from one generation to the next. In the case of the so-called 'Half Indian' Peter, as well as those adopted by 'white' parents such as Seba, Ashvin and Paul, it is quite clear that they consider 'Indianness' to be something inherited, which is part of them and exists even if it is not developed further. None of them has grown up socialised even partly by 'Indian' cultural practices. None of them knows an 'Indian' language since childhood, pursues 'Indian' religious practices or has ever lived in 'India' more than a few months. Even though the term 'Rasse', which is the equivalent to the English term 'race', is not used in 'Germany' to categorise humans ${ }^{50}$ and would most probably not be used by any of the interviewed, the concept of 'race' seems to inform this notion of 'Indianness'. ${ }^{51}$ Assuming that 'national' belongingness is inscribed in the body follows the racist division of humans into different 'races' and reproduces it. This is not surprising as although the generally accepted and represented self-image of 'Germany' is a non-racist one, the structures of racism are deeply inscribed into discourses and institutions tracing back to the 'Enlightenment'. ${ }^{52}$ Distinguishing people on the basis of the 'origin' of their genes and their physiognomic markers is something which is readily accepted in 'Germany' as 'natural' as long as it is not formulated in this explicit way.

Also Hari and Harsha seek to support their claim to 'Indianness' by referring back to ancestors, who migrated from 'India'. They ascribe them as migrants a legitimate claim to 'Indianness', which they can pass on to their descendants. Harsha in fact enforces this claim to genetic purity in the interview by mentioning that "in my family there was a lot of intermarriage". He offers an immigration history which traces his ancestors back to Sindh, but he remains vague in filling this history with details. Hari's search for an explanation of his family's 'Indianness' (as shown in the following excerpt from the interview) clearly illustrates the mythical character of the migration histories:

\footnotetext{
${ }^{50}$ Some authors avoid using the German term 'Rasse' by switching to the English term 'race' in German texts. They argue that the English term is widely used and less linked to racist ideology. See Eske Wollrad (2005), Weißsein im Widerspruch - Feministische Perspektiven auf Rassismus, Kultur und Religion, Königstein/Taunus: Ulrike Helmer Verlag, for a criticism of this argument.

${ }^{51}$ For theories of racism and a discussion of the socially constructed concept of 'race' see Eggers et al (2005) Terkessidis (2004) and Paul Mecheril (2004) Einführung in die Migrationspädagogik, Weinheim: Beltz.

${ }^{52}$ See in particular Eggers et al (2005) for this. Compare also Mechtild Gomolla and Frank-Olaf Radtke (2002) Institutionelle Diskriminerung - Die Herstellung ethnischer Differenz in der Schule, Opladen.
} 
Question: "What do you mean by saying that you are originally Indian? At some stage somebody has migrated from India to Afghanistan?”

Hari: "Yes."

Question: "How long ago was this?"

Hari: "I would like to know that as well. I would really appreciate it, if somebody would research that."

Question: "So your ancestors, grandparents and so on were ..."

Hari: "As far I have understood my uncle .. he is of the opinion that we were originally Hindus, migrated to Afghanistan, rather we fled there and then converted to Sikhism. In the case of my family this was as far as I know three generations back, my grandfather was the first to become a Sikh. Others say that we came as Sikhs one hundred, two hundred years ago. Nobody seems to really know."

Maybe because they know that their genetic link to 'India' is debatable both Harsha and Hari do not solely rely on it to legitimise their 'Indianness'. In the interview they emphasise in particular their 'culture' competence, thus shifting the attention to social markers of 'Indianness'. The concept of the 'second generation' in this context acquires a second meaning as it is the migrant generation, which socialises the 'second' into being 'Indian'. Harsha explains how he grew up with 'Indian' music and thus understands it better than those not socialised with it. Hari emphasises the importance of language competence, religious practice as well as the adherence to 'Indian' values and mentality, in particular with respect to family and partnership. He explains his sense of 'Indianness' with his experiences of familiarity and belongingness in 'India'. This familiarity with cultural practices is something which Peter, Seba, Ashvin and Paul cannot claim for themselves. Even if they attempt to a larger or smaller degree to acquire a form of 'culture' competence, they have not been socialised with it and thus can never attain it with the same implicitness as Hari and Harsha.

This understanding of 'Indianness' or rather 'Non-Germanness' on the basis of 'culture' competence can be found as well in the public discourses in 'Germany'. There 'Germanness' is defined through language competence, affiliation to Christianity and 'German' values. ${ }^{53}$ This mechanism of differentiating on the basis of 'culture' has been

\footnotetext{
${ }^{53}$ For an illustration of this see for example the guide for naturalisation from the German state Hessen: Hessisches Ministerium des Innern und für Sport (2006) Leitfaden: Wissen \& Werte in Deutschland und Europa, Wiesbaden.
} 
conceptualised by Etienne Balibar ${ }^{54}$ and has been termed cultural racism. In it the racist discourses do not any longer explicitly focus on the notion of biological 'race', but shift their focus to assumed 'cultural' difference. The mechanisms and functions of this form of othering remain the same as in the case of biological racism. A distinction is being constructed between 'us' and 'them' which is hierarchical and legitimises unequal power distribution and access to resources. A closer examination of the discourses shows that 'culture' is often attributed in an hereditary nature, i.e. it is something one is born with and which is linked to the parents. Thus to be accepted as a 'German' it is, despite the public discourses, not sufficient to know German, be a Christian and follow 'German' values. One needs to be one by descent to really qualify for recognition. 'Culture' thus carries on the connotation of 'race', the shift is more in terms than in meaning. 'Indians of the second generation' despite their 'German' language and culture competence will always remain the 'Others' as long as they are marked as such through some social or physiognomic attributes.

While in the cases described above both 'race' and 'culture' have been considered as important markers of 'Indianness', none of the quoted interview partners attributed a significant importance to citizenship. ${ }^{55}$ On the first sight this seems surprising as citizenship is the formal symbol of belongingness which regulates the access to many resources. ${ }^{56}$ In 'Germany' up to recently it, furthermore, was closely linked to notions of 'race' and 'purity'. But as Christiane and Peter were born as German citizens, Seba and Ashvin acquired it through adoption, Paul was naturalised when he was 14 years and Hari after his family was granted asylum, none of them anymore experiences exclusion on the basis of citizenship in 'Germany'. They rather experience the limited potential citizenship has to grant them belongingness. Their German passports do not make them unquestioned 'Germans'. 57 They all know that the seemingly straightforward definition of 'Indianness' through citizenship does not make much

\footnotetext{
${ }^{54}$ See Etienne Balibar (1990) “Gibt es einen 'Neo-Rassismus'?”, in Etienne Balibar and Immanuel Wallenstein (ed.), Rasse - Klasse - Nation. Ambivalente Identitäten, Hamburg.

${ }^{55}$ Compare Jessica Jacobsen (1997), "Perceptions of Britishness", in Nations and Nationalism, 3(2), July, 181-199, who in her analysis distinguishes between 'racial', 'cultural' and civic boundaries of 'Britishness'.

${ }^{56}$ See Mecheril (2003: 147-151).

${ }^{57}$ For a more detailed discussion see Urmila Goel (2006) "Ausgrenzung und Zugehörigkeit - Zur Rolle von Staatsbürgerschaft und Einbürgerung", in Christiane Brosius und Urmila Goel (2006, Hrsg.), masala.de - Menschen aus Südasien in Deutschland, Heidelberg: Draupadi-Verlag, 123-160.
} 
sense. 'Indianness' is not linked to this official status, it is something much more complex and something which cannot be explicitly defined. Different markers are part of determining 'Indianness' but there is no exact formula for this. This, however, does not imply that the claim to 'Indianness' can be made totally arbitrarily. There do exist accepted notions of 'Indianness' towards which the claims are made.

\section{The 'Standard Indian' in 'Germany'}

This seeming paradox of something vague and undefined, which nonetheless has normative powers can be explained by referring to Paul Mecheril's concept of the fictitious prototype of the 'Standard German'. ${ }^{58}$ He argues that although what a 'German' is cannot be defined, there are images of what it means to be a 'German'. There are notions of what a 'German' looks like, how he behaves, which preferences and sensibilities he has, what disgusts him and when he feels comfortable. ${ }^{59}$ These exist and are effective without them being nameable. In fact, their effectiveness is increased through this lack of definition as the notions cannot be challenged discursively.

The prototypical images develop according to Mecheril against the backdrop of specific living conditions and the collective history of dealing with these. He emphasises, however, that the 'Standard German' is not a condensed image of the living conditions nor a representation of the 'average' performance of the group. The prototype is the norm against which deviations are measured. If someone is considered not to deviate significantly from the prototype, he or she will be accepted as 'German'. If the person, however, due to some physiognomic or social markers is considered to deviate significantly, his or her claim to 'Germanness' will not be accepted without doubts. Those who are considered to deviate, will always be contested in their claim of belongingness. This explains why 'Other Germans' are other. They do not conform closely enough to the fictitious image of the 'Standard German'. 'Indians of the second generation' are accordingly excluded from what is considered to be 'German'. For 'white Germans' they are marked as 'Indians' since they sufficiently conform to the 'white Germans"' notion of a 'Standard Indian'.

\footnotetext{
${ }^{58}$ See Mecheril (2003, 211-212).

${ }^{59}$ Mecheril uses in this description only the male gender. I assume that he does so on purpose as the fictitious prototype is imagined in a society, which is not only determined by racism but also heteronormativity, and thus the prototype will be male.
} 
The fictitious prototype of a 'Standard Indian', however differs between those living in 'India', the 'white Germans' and 'Indians of the second generation'. Many of those marked as 'Indians' in 'Germany' will be marked as 'Germans' or at least 'foreigners' in 'India'. It is, for example, my experience that on the basis of physiognomic markers I am much less considered an 'Indian' in 'India' than in 'Germany'. This denial of belongingness experienced in 'India' on top of that in 'Germany' results in what Mecheril calls being doubly othered.

If one wants to analyse the claims to 'Indianness' of the so-called 'Half Indians', the adopted 'Germans' and the self described 'Afghan Indians' as well as their contestations one needs to understand that the 'Indians of the second generation' are faced by different prototypes depending on the environment in which they want their claims to be accepted. 'White Germans', 'Indians' in 'India' and those marked as 'Indians' in 'Germany' will focus on different attributes as essential aspects of their image of the 'Standard Indian'. Claims to 'Indianness' can accordingly be analysed only in their context. In doing so one has to take account of the fact that the notion of 'Indianness' in a context where multiple notions compete is even more fluid and vague than in a context where the point of reference is normatively unambiguous. The success of their claim to 'Indianness' is thus for the 'Indians of the second generation' more unpredictable than it is predictable that their claim to 'Germanness' will be refused.

\section{'Indianness' as a refuge in 'Germany'}

The context of the interviews was 'Germany'. The claims to and contestations of 'Indianness' thus have to be analysed in a 'German' context. This in turn is determined as Mecheril has shown by the norm of natio-ethno-cultural univocality. ${ }^{60} \mathrm{He}$ uses the term natio-ethno-cultural as the terms 'national', 'ethnic' and 'cultural' in themselves are vague and at the same time suggest the existence of these categories as essences. Using the made-up word refers to the notions of 'nation', 'ethnicity' and 'culture' and at the same time questions them. ${ }^{61}$ The logic of natio-ethno-cultural univocality is based

\footnotetext{
${ }^{60}$ See Mecheril (2003). In contrast to 'Britain' even hyphenated identities are not really thinkable in 'Germany'.

${ }^{61}$ Similar to Hall (1992) Mecheril (2003) argues that the notion of 'ethnicity' is loaded with essentialist notions. While Hall based on this argues for the development of 'new ethnicities', which are built on
} 
on the conviction that any person can belong to only one natio-ethno-cultural context at one time. Thus one can be either 'German' or 'Indian' but not both at the same time. This belief is inscribed both into formal and informal concepts of membership. ${ }^{62}$ Among the requirements of formal membership the exclusive citizenship law in 'Germany', which does not allow dual citizenship, is most important. The informal membership is regulated by the fictitious prototype of the 'Standard German', which does not cater for belongingness to multiple natio-ethno-cultural contexts. In fact within this normative discursive framework multiple belongingness cannot be thought. Those who belong at the same time to several contexts must be considered as joining what cannot be joined. ${ }^{63}$ Mecheril accordingly uses for them the term monster, i.e. a creature which unites the not unitable. Monsters, however, are threatening to those who are valuing purity and to the notions of purity themselves. They question the normative logic of the society and must thus be eliminated at least discursively.

'Indians of the second generation' are such monsters. They feel a sense of belongingness both to 'Germany' and to 'India' (and potentially to further contexts as well) and deviate from both fictitious prototypes. They have been brought up in 'Germany', were socialised there and live there. There they feel a sense of belongingness, ${ }^{64}$ want to act effectively ${ }^{65}$ and want to be accepted as a member. ${ }^{66}$ As has been shown many define themselves in fact as 'Germans'. At the same time they feel a belongingness to 'India' due to their knowledge about ancestry and stories being told to them, maybe through contacts to 'India', certainly through physiognomic and social markers and imaginations which stem from these ${ }^{67}$. 'India' thus in their perception becomes a potential perspective even if they have never been there or will never actually go. ${ }^{68}$ The potential perspective is particularly important as a refuge, in

difference rather than on essences, Mecheril uses the artificial term natio-ethno-cultural to underline the ambiguous meanings of the terms 'nation', 'ethnicity' and 'culture' and to refer to their everyday usage.

${ }^{62}$ See Mecheril $(2003,138-160)$.

${ }^{63}$ See Mecheril (2003, 323-325).

${ }^{64}$ See Mecheril $(2003,218-251)$ for a discussion of belongingness.

${ }^{65}$ See Mecheril $(2003,161-217)$ for a discussion of acting effectively.

${ }^{66}$ See Mecheril $(2003,138-160)$ for a discussion of membership.

${ }^{67}$ See Mecheril $(2003,27)$.

${ }^{68}$ This is similar to the importance 'Africa' attains in 'black' nationalism. For the 'German' context see, for example, the autobiography of the ,Black German' Charles M. Huber (2004), Ein Niederbayer im Senegal - Mein Leben zwischen zwei Welten, Frankfurt/Main: Scherz. 
case the situation in 'Germany' becomes unbearable. When I conducted field research about citizenship and naturalisation among 'Indians of the second generation' in 'Germany', ${ }^{69}$ this was a sentiment which was repeatedly expressed to me as a reason not to abandon the 'Indian' citizenship. Being an Indian citizen gives them the (imagined) security that they can flee to 'India' at any time. Within the logic of natio-ethno-cultural univocality this potential refuge from one context, however, seems particularly disturbing and monstrous. When in 1997 the 'German' government wanted to introduce dual citizenship, the conservative opposition successfully campaigned against it. They argued not only that one has to decide which context one wants to belong to exclusively but also that it would be highly 'unfair' if those with dual citizenship had something the 'pure Germans' did not have.

As Mecheril argues ${ }^{70}$ 'Germany' is the context where the 'Other Germans' daily need to act and be effective. It has for practical purposes much more relevance to their life than the context 'India', which most hardly visit. Accordingly the denial of belongingness to 'Germany' is felt much more directly. It is experienced on a daily basis in everyday interactions. Lacking effectiveness in 'India' and the refusal of belongingness there, however, are experienced much more seldom as the 'Indians of the second generation' are hardly in 'India'. Furthermore, 'India' is the context to which they are daily ascribed in their interactions in 'Germany'. It is thus much easier to imagine themselves as 'Indians' than as 'Germans'. If they do so, they can seemingly conform to the norm of univocal natio-ethno-cultural belongingness, which they have been socialised with. At the same time they can, by imagining to belong to 'India' rather than to 'Germany', take refuge from the experiences of othering and exclusion in 'Germany' (as long as they are in 'Germany'). ${ }^{71}$

The experiences of othering and exclusion seem to be what all of them have in common. Especially the 'Afghan Indians' and the adopted 'Germans' have told me of many experiences of racism in the interviews, even if they might not have used the term

\footnotetext{
${ }^{69}$ See Goel (2006).

${ }^{70}$ Mecheril $(2003,27)$.

${ }^{71}$ Compare the re-ethnicisation of the penakaran 'Chinese' in the Netherlands as 'Chinese' described by Ang $(2001,31)$.
} 
racism. ${ }^{72}$ Interview excerpts such as Martin's experiences at the cashpoint, Harsha's quoting a 'German' with “[y]ou are no German, because you do not look German”, Hari's search for a place "[w]here I do not experience myself as something alien.", Paul's explanation "I consider myself a German, but I am treated often as a foreigner, i.e. I am considered a foreigner" and Ashvin's account about his environment "[a]lso my parents and my friends say that an Indian woman simply suits me better, harmonises better with me" all illustrate that they experience othering in 'Germany'. They are considered as others and accordingly have accepted being such. Seba's use of the racist term 'coloureds' and Christiane's use of 'half-caste' to describe themselves, shows how much they have been socialised in a racist society and have internalised it's ascriptions. Peter is probably the only one who hardly ever encounters direct othering as he is only perceived to deviate significantly from the 'Standard German' if the observer knows that he has a biological father marked as an 'Indian'. There are no other physiognomic or social markers according to which he significantly deviates. But even Peter is faced with othering stereotypes about 'Indians' and is linked to these. He knows that his father is considered an 'Indian', follows the public racist discourses about 'Indians' and is faced by his mother's accounts about his father and his 'Indianness'. In the interview it becomes quite clear that he has learnt to consider his father as different because he is marked as an 'Indian'. Peter experiences othering thus mainly indirectly through his father $^{73}$ and in his socialised knowledge that by ancestry he himself must be different from the 'Germans'.

Against this backdrop, as Hari quite clearly says, "one has to define oneself somehow". All those quoted in this article somehow consider themselves 'German', but they do know that their claim to 'Germanness' will never be unquestioned. So they cannot rely on it purely. 'Indianness' hence becomes a seemingly 'natural' option of identification as this is the identity which is ascribed to them anyway. For those who are marked as 'Indians' in 'Germany' it also seems to be the context where they would experience the least othering. Even though they know that there will be no context where they will experience an absence of othering. Located in 'Germany', 'India' becomes a symbolic

\footnotetext{
${ }^{72}$ For different strategies in dealing with experiences of racism see Mareile Paske (2006), 'Andere Deutsche' - Strategien des Umgangs mit Rassismuserfahrungen, Frankfurt/Oder: Viadrina, $<$ http://www.urmila.de/UDG/Forschung/publikationen/Paske2006.pdf>

${ }^{73}$ Mecheril $(2003,67-71)$ argues that racism can also be experienced indirectly, when for example the one faced by racism is very close to you.
} 
place of refuge. It becomes a personal 'imaginary homeland' as Rushdie ${ }^{74}$ argues: "my India was just that: 'my' India, a version and no more than one version of all the hundreds of millions of possible versions."

Those portrayed in this article claim 'Indianness' although they know they do not conform to a pure essentialised notion of 'Indianness'. They manage for themselves to incorporate their impurity into this natio-ethno-cultural concept, which normatively requires univocality. They thus reinterpret 'ethnicity', incorporate difference and through their heterogeneous claims of 'Indianness' create what Hall' ${ }^{75}$ calls 'new ethnicities'. 'Indianness' in 'Germany' is something different from 'Indianness' somewhere else.It is heterogeneous, specific and new. This creation of something new happens implicitly in the struggle with and the aim to conform to essentialised notions of 'nation', 'ethnicity' and 'culture'. Most of those portrayed refer to 'Indianness' because unquestioned 'Germanness' is denied to them, not because they want to challenge the essentialised notions of natio-ethno-cultural concepts. ${ }^{76}$

The contestations of the claims as well as the vagueness of 'Indianness' described in this article show that being 'Indian' is no more 'natural' and unquestioned than being 'German'. One cannot fulfil a check list and become an 'Indian'. 'Indianness' like 'Germanness' is defined by the fictitious prototypes of the standard, which result from normative discourses about natio-ethno-cultural belongingness. Both concepts are constructions which legitimise existing power structures and access to resources.

If you want to participate in the structures and access the resources you need to play the rules of the game. 'Indians of the second generation' like Subhas and Rajesh attempt to do so. They have both accepted that they are excluded from 'Germanness' even though 'Germany' has always been their home and will stay so. As ethnic entrepreneurs (to use a phrase of Rogers Brubaker ${ }^{77}$ ) they claim and attempt to build a homogenised 'Indian

\footnotetext{
${ }^{74}$ See Rushdie $(1992,10)$.

${ }^{75}$ See Hall (1992).

${ }^{76}$ There are also 'Indians of the second generation', who explicitly oppose these essentialised notions. Paske (2006) portrays a young women, who distances herself both from 'Indianness' and 'Germanness', and rather focuses on her experiences of racism.

${ }^{77}$ Brubaker (2004) argues that ethnic entrepreneurs use the notion of 'ethnicity' to mobilise resources and in the process create the impression of an existing 'ethnic community'.
} 
community', which denies the internal heterogeneities and fits the norms of univocality. For this to be successful they have to distance themselves from those on the margins. But their attempts can never be fully successful as they like the others are monsters in the logic of univocal belongingness. ${ }^{78}$ Even if they define themselves as 'Indians' and discursively clean 'Indianness' of 'impurities', they will continue to belong to several natio-ethno-cultural contexts at the same time as their struggles with 'Germanness' illustrate.

\section{Bibliography}

Ang, Ien (2001) On not speaking Chinese - Living between Asia and the West, London and New York: Routledge.

Badawia, Tarek (2002) "Der Dritte Stuhl": Eine Grounded Theory-Studie zum kreativen Umgang bildungserfolgreicher Immigrantenjugendlicher mit kultureller Differenz, Frankfurt/Main.

Balibar, Ettiene (1990) "Gibt es einen 'Neo-Rassismus'?", in Etienne Balibar and Immanuel Wallenstein (ed.), Rasse - Klasse - Nation. Ambivalente Identitäten, Hamburg.

Barth, Fredrik (1969) Ethnic Groups and Boundaries, Boston.

Baumann, Gerd (1996) Contesting Culture - Discourses of identity in multi-ethnic London, Cambridge.

Bhabha, Homi K. (1994) The location of culture, London.

Brah, Avtar (1996) Cartographies of Diaspora - Contesting identities, London.

Brubaker, Rogers (2004) Ethnicity without groups, Cambridge: Harvard University Press.

Cohen, Anthony (1985) The symbolic construction of community, London.

Eggers, Maureen Maisha; Kilomba, Grada; Piesche, Peggy and Arndt, Susan (eds.) (2005) Mythen, Masken, Subjekte - Kritische Weißseinsforschung in Deutschland, Münster: Unrast.

Gajjala, Radhika (2004) cyber selves - Feminist ethnographies of South Asian women, Walnut Creek: Altamira Press.

Goel, Urmila (2005) "Fatima and theinder.net - A refuge in virtual space", in Angelika Fitz, Merle Kröger, Alexandra Schneider und Dorothee Wenner (ed.), Import Export - Cultural Transfer - India, Germany, Austria, Berlin: Parhas Verlag 201207.

\footnotetext{
${ }^{78}$ Compare Ang's (2001, 8-11) description of how the attempt to assimilate in the Netherlands must eventually fail.
} 
(2006) "Ausgrenzung und Zugehörigkeit - Zur Rolle von Staatsbürgerschaft und Einbürgerung", in Christiane Brosius und Urmila Goel (2006 Hrsg.), masala.de Menschen aus Südasien in Deutschland, Heidelberg: Draupadi-Verlag, 123-160.

(2007) "'Kinder statt Inder' - Normen, Grenzen und das Indernet", in Christine Riegel and Thomas Geisen (eds.), Jugend, Zugehörigkeit und Migration, Wiesbaden: VS Verlag, 163-181.

(2008) "The German internet portal Indernet - A space for multiple belongingness", in Gerard Goggin and Mark McClelland (eds.), Internationalizing Internet Studies, New York: Routledge (forthcoming).

Gomolla, Mechtild and Radtke, Frank-Olaf (2002) Institutionelle Diskriminerung - Die Herstellung ethnischer Differenz in der Schule, Opladen.

Hall, Stuart (1992) “New Ethnicities”, in James Donald and Ali Rattansi (eds.), 'Race', culture \& difference, London: Sage, 252-259.

(2000) Rassismus als ideologischer Diskurs“, in Nora Räthzel (ed. 2000), Theorien über Rassismus, Hamburg: Argument, 7-16.

Heft, Kathleen and Goel, Urmila (2006) Räume der zweiten Generation Dokumentation eines Workshops, Frankfurt/Oder: Viadrina.

Hessisches Ministerium des Innern und für Sport (2006) Leitfaden: Wissen \& Werte in Deutschland und Europa, Wiesbaden.

Huber, Charles M. (2004) Ein Niederbayer im Senegal - Mein Leben zwischen zwei Welten, Frankfurt/Main: Scherz.

Jacobsen, Jessica (1997) "Perceptions of Britishness", in Nations and Nationalism, 3(2), July, 181-199.

Jenkins, Richard (1997) Rethinking ethnicity - arguments and explorations, London.

Mecheril, Paul (1997) "Rassismuserfahrungen von Anderen Deutschen - eine Einzelfallbetrachtung", in Paul Mecheril and Thomas Teo (ed.), Psychologie und Rassismus, Hamburg., 175-201.

(2003) Prekäre Verhältnisse. Über natio-ethno-kulturelle (Mehrfach-) Zugehörigkeiten, Münster.

(2004) "Andere Deutsche gibt es nicht. Zusammenhänge zwischen subalterner Erfahrung und diskursiver Praxis", in AntiDiskriminierungsBüro Köln und cyberNomads (ed.), The Black Book. Deutschlands Häutungen, Frankfurt, 82-90.

(2004) Einführung in die Migrationspädagogik, Weinheim: Beltz.

Mecheril, Paul and Teo, Thomas (eds.) (1994) Andere Deutsche. Zur Lebenssituation von Menschen multiethnischer und multikultureller Herkunft, Berlin.

Miles, Robert (2000) "Bedeutungskonstitution und der Begriff des Rassismus", in Räthzel, Nora (ed.) (2000) Theorien über Rassismus, Hamburg: Argument , 1733.

Mitra, Ananda (1997) "Virtual commonality: Looking for India on the internet", in Jones, Steven (ed.) Virtual Culture. Identity and communication in cybersociety, London: Sage, 55-79.

Molt, Christiane (2006) "In search of Indo-European identities", in Voll, Klaus and Beierlein, Doreen (eds.) Rising India - Europe's Partner?, Berlin: Weißensee Verlag, 963-969. 
Paske, Mareile (2006) 'Andere Deutsche' - Strategien des Umgangs mit Rassismuserfahrungen, Frankfurt/Oder: Viadrina, available online: $<$ http://www.urmila.de/UDG/Forschung/publikationen/Paske2006.pdf $>$ (accessed 2007).

Riegel, Christine (2004) Im Kampf um Zugehörigkeit und Anerkennung Orientierungen und Handlungsformen von jungen Migrantinnen, Frankfurt.

Rushdie, Salman (1991) "Imaginary Homelands", in Salman Rushdie, Imaginary Homelands, London: Granta Books.

Terkessidis, Mark (2004) Die Banalität des Rassismus - Migranten zweiter Generation entwickeln eine neue Perspektive, Bielefeld.

Wollrad, Eske (2005) Weißsein im Widerspruch - Feministische Perspektiven auf Rassismus, Kultur und Religion, Königstein/Taunus: Ulrike Helmer Verlag. 